\title{
Regional public support to airlines and airports: an unsolved puzzle
}

\author{
Ramón Núñez-Sánchez*
}

October 20, 2014

\begin{abstract}
This paper proposes a structural model to explain the motivation of regional public authorities to arrange marketing agreements for route and traffic development. Moreover, using data from Spanish airports, we empirically test this model obtaining the (inverse) demand function according to the preferences of public authorities. The results show the sensibility in the demand for aircraft operations of regional public agencies increases as the size of the airport also increases. Finally, we propose an empirical method to determine the market power of airlines within these marketing agreements in a particular airport or route.
\end{abstract}

\section{Introduction}

In recent years, some airports have presented important growths levels of traffic due to the liberalization in the air transport market. In some cases, this phenomenon has been related to the existence of new transport policy tools which aim to promote the use of airport infrastructure with idle capacity. In this way, an increasing number of regional airports have received the support of their regional governments through financial arrangements with air carriers in order to open new routes, as well as to provide advertising services conditioned to the permanence of the air carrier at a given airport. Indeed, airport managers have more incentives to negociate long-term contracts with air carriers in order to reduce the risk of traffic loss for their installations (Gillen, 2011). In Europe, these types of agreements among regional governments and air carriers have been controversial, especially for those full service carriers (FSCs) which have made a claim to the European Commission, asking whether those subsidies should not be considered as illegal. This has been the case of Charleroi airport and Ryanair (Barbot, 2006). In 2001, the Walloonian government, owner of Charleroi airport, signed an agreement with Ryanair in order to promote the

*Universidad de Cantabria. Departamento de Economía. Avda. Los Castros, s/n, 39005, Santander (Spain). E-mail: nunezr@unican.es. Phone: +34942206728. 
use of the Charleroi facilities. Thus, the airport agreed to give a discount in landing fees and handling charges for a period of 15 years, among other measures, in exchange for Ryanair to commit itself to using Charleroi as an operating base for the same period. Three years later, the European Commission established that reductions in these fees and charges were partially incompatible with the common-market principles concerning state aids. The analysis and decission of Charleroi-Ryanair case allowed the European Commission to develop guidelines on the financing of airports and start-up aids to airlines departing from regional airports in 2005. At the end of 2008, the European Court of First Instance annulled the Commission's Decision. In 2014 the Commission adopted new guidelines with the aim of adjusting to the new economic context (European Commission, 2014). In this sense, start-up aid to airlines will only be considered compatible for routes linking an airport with less than three million passengers per year and may cover up to $50 \%$ of airport charges in respect of a route for a maximum period of three years. Additionally, for those connections which are already operated by a high-speed rail service or by another airport in the same catchment are, such air route will not be eligible for start-up aid.

In Spain, the Comisión Nacional Competencia ('National Competition Commission') issued a report about the public funds provided by regional public authorities to different airlines, with the aim of increasing the flow of travelers to certain destinations for the period 2007-2011 (CNC, 2011) ${ }^{1}$. The analysis focuses specifically on those marketing agreements concluded between public authorities and airlines. In this type of operations, the airline agrees to incorporate advertising for tourism purposes in different channels (on board magazine,webpage or promotional tickets) and also commits to opening new routes or maintaining those already available with origins or destinations in a certain airport. Meanwhile, the public authority agrees to pay for services received. As the report remarks, the price of the services included in the instruments used were determined from rates and average costs set by the airlines, although these rates have not been disclosed in the investigation (CNC, 2011; page 52).

Among the reasons why the CNC considers it relevant to study this type of public assistance are: the increasing use of public support for the maintenance of routes at certain airports, and the potential distortion that can generate in the allocation of productive factors. Finally, the report notes that the regional public authorities have not reported any such public support to the European Commission in any of the cases. This fact could reveal the perception of public agencies that this public support is not considered possible State aid, subject to the State aid general rules and the specific Community guidelines on State aid to airports and airlines (2005).

The overall volume was nearly of 250 million Euros, concentrated in a few

\footnotetext{
${ }^{1}$ In October 2013, the government of Spain created the National Commission on Markets and Competition (CNMC in Spanish) from the merger of five agencies: National Energy Commission (CNE), Commission for the Telecommunications Market (CMT), National Competition Commission (CNC), National Commission Sector Postal and Railway and Airport Committee Regulation. The fusion of the bodies was justified by the cost savings that could generate public finances.
} 
number of airlines. The distribution of public support was also not uniform across Spanish airports. Furthermore, the report showed that airports presented a negative correlation between their ratio of public funds per passenger and their corresponding traffic growth rates. From these results, one might ask the question of the suitability of this type of support. A cost-benefit analysis of this public policy could determine whether the policy followed by numerous government generates some kind of gains in terms of social welfare. However, this type of analysis is beyond the scope of this work due to its enormous complexity.

The literature related with bilateral agreements between airport operators or local authorities on the one side and airlines on the other it is recent and scarce. Barbot (2006) analyses the effects of subsidies for secondary airports on competition between low cost and full-scheduled carriers. This study also assesses a case study of the Ryanair-Charleroi airport agreement. The main results are that subsidization provokes a growth in demand, adding new users and a switch of passengers from full-scheduled carriers to low cost airlines. On the airport side, the proposed model shows that the airport may benefit more from the arrangement than the subsidised air carrier, depending on its efficiency.

Malina et al. (2012) investigate incentive programs between airports and airlines for the most important European airports. They find that bilateral agreements serve as a substitute for published incentive programs. However, they do not study specifically these bilateral agreements due to the scarcity of official sources. Nonetheless, they point out that the largest airports exclusively employ published airport incentive programs whereas medium and small size airports use more intensively bilateral agreements.

Allroggen et al. (2013) assess factors that impact on presence for incentives for route and traffic development such as economic regulation, airport competition, airport ownership or airports' catchment area. Among other results, they show that airports are more likely to offer incentives for route development if they are regulated on the basis of costs or price-caps, or/and they are controlled by public entities.

However, no previous theoretical or empirical study has examined the bilateral agreements between regional public authorities and airlines in any detail.

In this paper we propose a structural model to explain the motivation of regional public authorities to arrange marketing agreements in order to attract new operators for their corresponding airports. Moreover, using data from Spanish airports, we empirically test this model obtaining the demand function according to the expenditure preferences of public authorities. Finally, we propose an empirical method to determine the market power of airlines within these marketing agreements in a particular airport or route. This measure may be particularly relevant in order to know which variables could explain the large variability of public funds in the bargaining process of marketing agreements between public authorities and airlines.

The paper is structured as follows. In Section 2 we describe the main features of the Spanish airport system. The theoretical model is presented in Section 3. Section 4 shows the econometric specification. The discussion of data and 
econometric results are explained in Section 5. In Section 6 we propose an application of the demand estimates in order to calculate the airline's bargaining power for marketing agreements with public authorities. Finally, in Section 7, we present the conclussions and policy implications regarding the public funds perceived by airlines.

\section{Spanish airport system}

The Spanish airport system is managed by Aeropuertos Españoles y Navegación Aérea, Aena ('Spanish Airports and Air Navigation'), a public-owned entity which owns and operates the most important airports in Spain, dependent on the Ministerio de Fomento ('Ministry of Development') since 1990. It is considered one of the main airport operators in the world, given that it manages 47 airports and 2 heliports in Spain and participates directly or indirectly in another 27 airports worldwide. Unlike other airport systems, the Spanish system has always been characterized by high centralization in the decision-making process through Aena, which manages all Spanish airports, barely taking into account their different characteristics. Thus, the funding mechanism of airport investments is made through a common fund, where no airport is accountable in terms of their operation and where cross-subsidies are present. In this sense, Bel and Fageda (2009) point to the existence of such subsidies mainly from specialized airports in tourist traffic to the major airport infrastructure. In this way, 14 of the Spanish airports presented operating profits, whereas 33 had operating losses.

This type of management is different from that presented other transport infrastructure in Spain . This is the case of Spanish ports, whose reforms of 1992 and 1997 led to the decentralization of decision-making of each port authority with the participation of regional authorities on their boards, while they were forced to comply with the principle of financial self-sufficiency .

Moreover, their pricing policy is uniform for the entire system and regulated by Law (Act 25/1998) given that airports charges are considered public fees. This regulation differentiates three types of airports depending of their levels of traffic in order to promote higher traffic level in those secondary airports. However, the annual update of these public fees is also uniform for every airport, so do not necessarily correspond with costs. Another important feature of the Spanish airport system is the huge investment process which Aena implemented for the 2000-2010 period, more than eighteen thousand millions of euros, in order to increase the capacity of the incumbent commercial airports, as well as the creation of new ones in low-density population regions. This is the case of Burgos Airport (opened in 2008) or the Huesca-Pirineos Airport (considered commercial in 2000). One of the aims of the transport infrastructure policy of this decade is the promotion of regional development through investments in highways, airports and high-speed rail systems. This process ends in 2010 with a total debt of Aena of fourteen thousand million Euros.

In 2010, Act 13/2010 presented a new legal framework for the modernisation 
and liberalisation of management of Spanish airports. The new rules aimed to transform the airport model into a more decentralised management system, increasing the private sector collaboration. In this way, the Law created a new firm Aena Aeropuertos ('Aena Airports'), whose capital initially belonged to AENA, but provided the possibility of private capital inflows in the future.

Thus, in July 2011 the Council of Ministers approved the agreement authorizing the sale of shares of Aena Aeropuertos to a maximum of 49 percent of its share capital. At the same time, it authorised the creation of concession societies for the airports of Madrid-Barajas and Barcelona-El Prat in order to privatise 90 percent of their capital. The new regulation encouraged individualized management of airports by two alternative schemes: a) A concession of airport services, in which the concessionaire freely managed the airport at his own risk, or b) The creation of subsidiaries, which applied the same rules set for the firm Aena Aeropuertos.

However, in January 2012 the new elected government definitely canceled the auction for the concession of both airports given that the process of privatisation was incompatible with its proposed airport management model. In this sense, the Minister of Transport acknowledged that the privatisation of both airports would have generated competition between Madrid-Barajas and Barcelona El Prat, when the Minitry's intention was that Spanish airports would compete with major global hubs. In this context and during the last years, Spanish airports have not had any tools that would allow them to compete, trying to improve their number of routes and passenger volume. However, through different mechanisms, regional public authorities have tried to promote airport infrastructure located in its territory. This task has not taken place without difficulties because they cannot take part in decision-making processes regarding investments in capacity, quality or pricing ${ }^{2}$.

Finally, in June 2014 the Spanish government approved partial privatization of Aena Aeropuertos, which will take place between September-November 2014. The Spanish government would maintain 51 percent of total shares and therefore control of the company. This model of privatization did not convince to the Spanish regulatory agency, the Comisión Nacional de los Mercados y la Competencia ('National Commission of Markets and Competition'), which argued that the imposition of a public-private monopoly preserves the status-quo of airports but inhibits competition among airports.

\section{Theoretical model}

We consider that the regional public agency presents the following utility function:

$$
U(Y, G)
$$

\footnotetext{
${ }^{2}$ An interesting case study of the use of subsidies to the promotion of airport infrastructure is related by Bel (2009), for the case of Girona airport.
} 
where $Y$ represents total aircraft movements in the airport located in its region and $G$ represents the public expenditure in tourism sector excluding those public funds for tourism purposes perceived by airlines. We consider that $\frac{\partial U(.)}{\partial Y}>0$, $\frac{\partial U(.)}{\partial G}>0$ and $\frac{\partial^{2} U(.)}{\partial Y^{2}}<0, \frac{\partial U^{2}(.)}{\partial G^{2}}<0$. We assume that $Y$ is distributed as:

$$
Y(S)=\left\{\begin{array}{ccc}
Y_{0} & \text { if } & S=0 \\
Y_{0}+Y_{S}(S) & \text { if } & S>0
\end{array}\right.
$$

where $Y_{0}$ represents those aircraft movements in the airport which do not perceive any public fund that we call natural aircraft movements and $Y_{S}(S)$ the rest of aircraft movements which depend on the volume of public funds from marketing agreements between public authorities and airlines. We assume that $\frac{\partial Y_{S}(S)}{\partial S}>0$ and $\frac{\partial^{2} Y_{S}(S)}{\partial S^{2}}=0$

$$
Y_{S}=\alpha S, \alpha>0
$$

Thus, the decision problem of the regional public authority is defined as:

$$
\begin{aligned}
& \max _{S, G} U(Y(S), G) \\
& \text { s.t. } \quad S+G=B
\end{aligned}
$$

where $B$ is defined as the total budget for the regional public authority. Using equations 2 and 3, we may also express the budget constraint as:

$$
G=\left\{\begin{array}{ccc}
B & \text { if } & S=0 \\
\left(B+\frac{Y_{0}}{\alpha}\right)-\frac{Y}{\alpha} & \text { if } & S>0
\end{array}\right.
$$

The budget constraint shows that public authority has to decide either to arrange marketing agreements with airlines or spend in other tourism-related activities. The equilibrium will be characterized by the pair $\left(S^{e}, G^{e}\right)$ such that: $\left(S^{e}, G^{e}\right)=\max \left\{U\left(Y\left(S^{*}\right), G^{*}\right), U\left(Y(0), G^{* *}\right)\right\}$, where $\left(S^{*}, G^{*}\right)$ is the interior solution. Rearranging the FOC interior conditions of 4 we obtain that, for the case of $S>0$, public agency should allocate its budget in order to fullfil the following condition:

$$
M R S_{Y}^{G}=-\frac{d G}{d Y}=\frac{\frac{\partial U(.)}{\partial Y}}{\frac{\partial U(.)}{\partial G}}=\frac{1}{\alpha} \quad \text { if } \quad S>0
$$

otherwise:

$$
M R S_{Y}^{G}=-\frac{d G}{d Y}=\frac{\frac{\partial U(\cdot)}{\partial Y}}{\frac{\partial U(\cdot)}{\partial G}}=0 \quad \text { if } \quad S=0
$$

Figure 1 shows this argument geometrically. We observe the situation in which the optimal solution is $\left(Y(0), G^{* *}\right)$. In this case, the aircraft movements in the airport would be $Y_{0}$, and $G^{* *} \equiv B$. From 4 we obtain the the public expenditure function for marketing agreements with airlines of the regional public agency,

$$
S=S\left(Y_{0}, B\right)
$$


This function specifies what the public agency would spend on marketing agreements with airlines for each natural aircraft movements and budget situation, assuming it perfectly solves the utility maximization problem. In order to improve its economic interpretation, we may rearrange equation 7 dividing both sides by $Y$,

$$
s=s\left(Y_{0}, B, Y\right)
$$

where $s=S / Y$ is the average public funds, which is the ratio between public funds allocated for marketing agreements and total aircraft movements. We interpret this equation 8 as an "inverse demand function" for the public authority in the sense that expresses the maximum average public fund that is willing to grant for a certain amount of additional aircraft movements, given the monetary budget for tourism-purposes and the natural aircraft movements. From this framework, we are able to obtain relevant information about how sensitive willingness to pay is in different situations and contexts for public authorities according to their preferences.

\section{Econometric specification}

\subsection{Tobit models with exogenous regressors}

As we have mentioned in previous sections, some public agencies do not grant any subsidy in order to increase aircraft movements in airports located in their region. So, the dependent variable of the specification $8, s$, follows the next pattern:

$$
s=\left\{\begin{array}{lll}
s^{*} & \text { if } \quad s^{*}>0 \\
0 & \text { if } & s^{*} \leq 0
\end{array}\right.
$$

where $s^{*}$ is considered as a unobserved latent variable. In this context, OLS estimation using censored data will lead to inconsistent estimation of the parameters. Then, we may use a Tobit model, which allows us to control our censored sample but requires the strong assumption about normality and homoskedasticity. The Tobit model is therefore often too restrictive in practice, specially for those variables which present skewness, as is the case of our variable of interest, $s$. However, we may circumvent this problem taking logs in our variable and considering as a lognormal where we observe (Cameron and Trivedi, 2005)

$$
s=\left\{\begin{array}{ccc}
s^{*} & \text { if } & \ln \left(s^{*}\right)>s_{0} \\
0 & \text { if } & \ln \left(s^{*}\right) \leq s_{0}
\end{array}\right.
$$

where $s_{0} \neq 0$.

Given that natural aircraft movements, $Y_{0}$ is not observable for the econometrician we consider $\mathbf{Z}_{1}$ as the vector of the "reduced-form" variables that 
determine the value of $Y_{0}$. Take $\operatorname{logs}$ in 8 we have the following econometric relationship:

$$
\ln (s)=\max \left[s_{0}, \mathbf{z}_{1} \boldsymbol{\delta}_{11}+\delta_{12} \ln (B)-\delta_{13} \ln (Y)+u_{1}\right]
$$

\subsection{Tobit models with endogenous regressors}

Following Wooldridge (2002), we consider a type I Tobit model which includes $Y$ as an endogenous explanatory variable. We consider the structural public agency demand model

$$
\begin{gathered}
\ln (Y)=\mathbf{z}_{1} \boldsymbol{\alpha}_{11}+\alpha_{12} \ln (B)+\mathbf{z}_{2} \boldsymbol{\alpha}_{13}+v_{1} \\
\ln (s)=\max \left[s_{0}, \mathbf{z}_{1} \boldsymbol{\alpha}_{21}+\alpha_{22} \ln (B)-\alpha_{23} \ln (Y)+v_{2}\right]
\end{gathered}
$$

where $\left(v_{1}, v_{2}\right)$ are zero-mean normally distributed, independent of $\mathbf{z}$. If $v_{1}$ and $v_{2}$ are correlated, then $Y$ is endogenous. Finally, we need that $\boldsymbol{\alpha}_{13} \neq 0$ in order to solve the identification problem.

\section{Data and description}

\subsection{Data}

Our analysis uses the results of the survey carried out by CNC (2011), which focus on those actions of administrations and public agencies in order to increase the flow of passengers to certain destinations from 2007 until 2011. Among them, we find public funds which were granted to airlines for opening new routes or financial arrangements aimed at the provision of advertising or tourism promotion services by the airline in exchange for their permanence at a particular airport for a certain period of time ${ }^{3}$. To collect this information, the CNC sent a questionnaire to all regional public authorities, Aena, the Tourism Institute of Spain (Turespaña) and those airlines with more than five million passengers per year in 2010 (Iberia traffic Ryanair, Air Europa, Spanir, Air Nostrum, Vueling, EasyJet and AirBerlin). Additionally, the CNC required all financial agreements whose main objective had been advertising or tourism promotion to be arried out by the airlines. As we see in Figure 2 more than half of the contracts presented an amount less than half a million Euros while sixteen contracts exceeded two million Euros.

Potential beneficiaries of public funds arising from these contracts and agreements are the airlines directly, and airports, indirectly. Regarding airlines, the emergence of low cost airlines in the early twenty-first century brought new opportunities for those regional airports, reducing ticket prices and generating

\footnotetext{
${ }^{3}$ As remarks the Comisión Nacional de la Competencia, given that none of these public agencies have notified to the European Commission in order to enforce the State Aid Rules and the Guidelines, they probably do not consider them as a public aid. However, the opening of investigations by the European Commission in some airports in different European countries (France, Germany or Romania) make relevant the study of such subsidies in the Spanish case.
} 
a change in the structure of the aviation market. However, as pointed out by the CNC in its report Air Nostrum, a franchisee company of regional Iberia flights, is the largest recipient of such funds. Second, Ryanair gets an increasing amount of public funds. Third, Lagunair company that went bankrupt in 2009 and fourth, Vueling, the low-cost carrier.

As regards airports, they benefit indirectly from such public funds to increase the number of routes or frequencies of the existing ones. Zaragoza, León, Santander, Valladolid or Burgos were the main beneficiaries; all of them considered secondary regional airports given that all of them carried a lot less than 1.5 million passengers per year. In this way, some regional agencies such as Castilla y León, Aragón, Galicia or Cantabria have distributed public funds worth over 20 million Euros for the period 2007-2011. On the other hand, other administrations have not considered it relevant to reach agreements with carriers in order to tie some airlines to the airports located in their regions. This is the case of Navarra, Madrid or Andalucía (Figure 3). In this way, we observe that some of the most important Spanish airports do not benefit from these agreements. This is the case of Barcelona, Bilbao, Jerez or Sevilla. Finally, as mention CNC (2011), public funds have been increasing for the period 2007-2011. In this way, in 2007 almost 30 million Euros were granted to airlines, whereas in 2009 the total amount achieved 62.5 million Euros .

\subsection{Variables}

In our econometric specification the dependent variable is the average public funds granted by public authorities to airlines. Unfortunately, the CNC report does not provide data disagregated by airline, so we just observe those agregated public funds by airport ${ }^{4}$. As we mentioned in previous sections, the average subsidy $(s)$ is calculated as the total amount of public funds by airport over the total aircraft movements in the airport $(Y)$. This variable was obtained from CNC (2011) and Aena (2013) Regarding the explanatory variables, the variable tourism-oriented budget $(B)$ was collected from the general budgets of the corresponding regions ${ }^{5}$. Population ( of the province where the airport is located (INE, 2013) and distance (dist) shows the distance of the nearest airport, expressed in kilometers. These two variables try to control the unobservable variable $Y_{0}$, natural aircraft movements. Table 1 shows the main summary statistics for these variables ${ }^{6}$.

\footnotetext{
${ }^{4}$ In some cases, tourism promotion contracts between public agencies and airlines did not link this promotion of the use of a particular airport. Therefore, for regions with multiple airports, which was not specified which ones were the beneficiaries, the amount of the agreements have been distributed uniformly (CNC, 2011).

${ }^{5}$ The Spanish Public Administration Ministry provides detailed information about the different regional general budgets in the following link: http://serviciosweb.meh.es/apps/publicacionpresupuestos/aspx/inicio.aspx

${ }^{6}$ As we mentioned in previous sections, Aena manages 47 airports and 2 heliports in Spain. However, a significant number of them do not have commercial flights. This is the case of Ceuta, Córdoba, Cuatro Vientos, Torrejón, Sabadell and Son Bonet. In our analysis, we do not have included them in order to mantein homogeneity in our sample.
} 


\section{Econometric results}

Table 2 reports the results obtained for different specifications of the Tobit model presented in Section 4. Specification (1) shows a standard Tobit model whereas in specification (2) consider the posibility of endogenous regressors. In particular, we treat the variable aircraft movements, $Y$, as an endogenous explanatory variable. The set of instruments used for this variable are related with the fees paid to the airports. Given that the actual fees are not observable for each airport, we proxy them by using dummies variables, which capture the different categories of Spanish airports. Until 2011, Spanish regulation had considered three categories of airports. Every category has its own fees. The parametric (MLE) estimation method of specification (2) assumes that the structural (Eq.13) and reduced-form (Eq.12) equation errors are jointly normally distributed. The results are consistent for all the specifications.

The variable total aircraft movements $(Y)$ is highly significant and present a negative sign, supporting the downward sloping of the "inverse demand curve" for public authorities. In specification (2) we present a Wald test of the exogeneity of $Y$. In this case, we reject the null hypothesis of exogeneity.

The coefficient of the variable tourism-oriented budget $(B)$ of public authorities is also negative and statistically different to zero. This result shows the negative relationship between the total amount of tourism-oriented budgets and the average public funds perceived for airlines in a particular airport. Thus, those airports located in regions with higher tourist-oriented budgets present lower average subsidies. This result suggests that those regions with high specialization in the tourism sector do not use these type of contracts and agreements in order to increase the flow of passengers if we compare them with other less-specializated regions. Aditionally, considering the theoretical model developed in previous sections we may interpret that public agencies consider the existence of additional aircraft movements as an inferior good.

Regarding the variables population ( $p o p)$ and distance (dist) are both positive and statistically significant. This suggests that airports with larger influence areas (with the possibility of the existence of density economics) benefit of servicing airlines which receive higher average public funds. The positive coefficient related to distance supports the idea that public authorities do not consider the granting these contracts could be the way to increase competition among nearer airports. This latter finding is consistent with the results of Allroggen et al. (2013) for European airports, which show that airports are less likely to introduce incentives for route development if they face higher competition from other airports.

Last, we have included both temporal dummies and regional dummies in order to capture unobservable effects ${ }^{7}$. Time effects are jointly significant. Given that we have removed the dummy associated to the year 2011, the results suggest that the average public funds for public agencias decreases in this period.

Table 3 reports elasticity measures for the specification (2) using different

\footnotetext{
${ }^{7}$ Coefficient related to regional dummies are also available under request to the authors.
} 
values of the variable total aircraft movements $(Y)$. Regarding the elasticity of this variable $\varepsilon_{s, Y}=\frac{\partial s}{\partial Y} \frac{Y}{s}$, results show a negative relationship between the sensisibility of average public funds and size (in terms of aircraft movements) of the airport. The sensibility of average subsidies of regional public agency is larger when the size of the airport is smaller. So, public authorities are willing to grant higher average subsidies in order to retain aircraft movements as the size of airport decreases. This result seems logical, given that in some of the smaller Spanish airports, just one airline operate on them. This is the case of Badajoz, Burgos, or La Rioja, in which only the company Air Nostrum provides flights. Calculating the inverse of this variable, we obtain $\varepsilon_{Y, s}=\frac{\partial Y}{\partial s} \frac{s}{Y}$, the elasticity of the aircraft movements demand for public authorities. The sensibility of demand for aircraft operations of regional public agency increases as the size of the airport also increases.

\section{Application of the demand estimates}

We have specified the inverse demand estimation procedure and elasticity estimates which can be useful for the economic analysis of public funds perceived by airlines. We now consider a possible application in order to use these estimates. We propose an oligopoly model à la Cournot in which airlines set capacities simultaneously in a certain route or airport.

We consider the decision problem of the first stage for an airline which operates in a particular route or airport and perceives public funds from a marketing agreement. In the second stage, the airline would decide fares once it has installed capacity in a particular route or airport. In this application we do not consider this second stage due to the limitations of data concerned to public funds. We demonstrate that is relevant gather information about the sensibility of demand, in order to determine the market power of the airlines in the bargaining process of marketing agreements between public authorities and airlines. This model may be tested either in a particular route or airport. First, we define the decision problem of an airline as

$$
\max _{y_{i}} \Pi\left(y_{i}, y_{-i}\right) \equiv s(Y) y_{i}-C_{i}\left(y_{i}\right)
$$

where $y_{i}$ is the aircraft operations of the carrier $i, y_{-i}$ is defined as the aicraft operations of other carriers in the same route or airport and $s(Y)$ expreses the inverse demand function of public authorities, which we define.in section 3.

The first-order condition of profit maximization is

$$
\frac{\partial s(Y)}{\partial Y} \frac{\partial Y}{\partial y_{i}} y_{i}+s(Y)-\frac{\partial C_{i}\left(q_{i}\right)}{\partial y_{i}}=0
$$

After some arrangements, we can rewrite 14 as

$$
s(Y)\left(1-\frac{\alpha_{i}}{\varepsilon_{Y, s}}\right)=c_{i}^{\prime}
$$


where $\alpha_{i}=\frac{y_{i}}{Y}$ is defined as the market share of airline $i$. We can also express the equation 15 as

$$
\frac{s(Y)-c_{i}^{\prime}}{s(Y)}=-\frac{\alpha_{i}}{\varepsilon_{Y, s}}
$$

where $\alpha_{i}=\frac{y_{i}}{Y}$ is defined as the market share of airline $i$. Hence, this model predicts that in a given market, a larger airline should have a larger markup. If we weight up airlines by their market shares, we obtain the following expression

$$
s(Y)\left(\alpha_{i}-\frac{\alpha_{i}^{2}}{\varepsilon_{Y, s}}\right)=\alpha_{i} c_{i}^{\prime}
$$

Next, we aggregate the first-order conditions for all the airlines

$$
s(Y)\left(1-\frac{H}{\varepsilon_{Y, s}}\right)=\sum_{i=1}^{N} \alpha_{i} c_{i}^{\prime}
$$

where $H=\sum_{i=1}^{N} \alpha_{i}^{2}$ is defined as Herfindahl index, which measures the degree of concentration of the airlines in a particular route or airport. Re-arranging

$$
\frac{s(Y)-\sum_{i=1}^{N} \alpha_{i} c_{i}^{\prime}}{s(Y)}=-\frac{H}{\varepsilon_{Y, s}}
$$

We conclude that the average Lerner index is proportional to the Herfindahl index. Then, calculating the Herfindahl index and estimating the public funds elasticity of demand allows for calculation of the average markup in a particular route or airport. Equation 19 also allows to evaluate the existence of a monopoly in a particular airport or route, given that in that case, the Herfindahl index would be equal to one. Therefore, the Lerner index in this case would be inversely proportional to the elasticy of the public authority demand. Therefore, first we have calculated the Herfindahl index using data from statistics of Aena website, given the availability of the airlines' market shares for each airport. Secondly, we have estimated the individual elasticity $\varepsilon_{Y, s}$ for each airport. Thus, using equation 19 we estimate the average bargaining power of airlines.

Table 4 reports the average mark-up for airlines which perceives public funds in the Spanish airports for the period 2007-2011. These estimates ranges from the minimum value, 0.007 but not statitically different from zero, which corresponds to Málaga to the maximum value, 4.234, of La Gomera. Other airports which present significant high markups of airlines are: Girona (3.951), Reus (3.929) or Melilla (3.871) In these airports the Herfindahl index shows the existence of only one air carrier. In the case of La Gomera, the regional air carrier Binter Canarias is the monopolist which just operates in inter-islands flights between the different Canary Islands. For the Catalonian airports of Girona and Reus it is Ryanair, the only air carrier that operates with regular flights. 
Moreover, both airports are considered as operating bases for Ryanair ${ }^{8}$ Finally, in Melilla located in Northern Africa, the only company which operates is Air Nostrum. Regarding those airports which present low average mark-up of their air carriers, they present similar characteristics, given that all of them are located in important tourism destinations of Canary Islands. This is the case of Lanzarote (0.212), Fuerteventura (0.264), Tenerife Sur (0.345) or Gran Canaria (0.383).

Finally, in Figure 4 we plot air carrier's mark-up for every airport and their size in terms of aircraft movements. We demonstrate the negative relationship between the bargaining power of airlines and the size of the airport.

\section{Conclussions}

In this analysis, we propose a structural model to evaluate the motivation of regional public authorities to arrange marketing agreements for route and traffic development in their corresponding airports. Then, we empirically test the model using a tobit instrumental variable approach in order to assess factors that may affect the willingness of public funds that public authorities grant. We demonstrate that: the inverse demand curve for public authorities is downward sloping, the negative relationship between the total amount tourism-oriented budget and the average public fund, and the influence of external factors such as the population of the catchment area or the distance of the nearest airport. Additionally, we observe that the sensibility of demand for aircraft operations of regional public agencies increases the larger as the size of the airport also increases. Finally, we present an application of the proposed model to evaluate the market power of airlines within these marketing agreements in a particular airport or route, using the estimates of elasticities of demand and the Herfindahl indexes in a particular route or airport. The results show that those airports considered as operating bases for a particular airline (Reus, Girona) and those located a in low population territory (La Gomera, Melilla) present the highest airline's mark-ups, whereas the lowest mark-ups correspond to those airports located in the most important touristic destinations in Canary Islands (Lanzarote, Fuerteventura, Tenerife Sur, Cran Canaria). We believe that this methodology may be used either for regional public authorities, airlines, airport managers or even the competition commission.

We also want to highlight some limitations in this study. While we appreciate the efforts made by the CNC, Comisión Nacional de la Competencia, to gather information from the public funds allocated to the airlines on tourism oriented marketing agreements, we believe that the distribution of the funds for each route and airline should also be available. Thus, it would be possible

\footnotetext{
${ }^{8}$ The bargaining power of Ryanair was demonstrated in 2011 when the company threatened to withdraw its base at Reus airport, after asking 15 million euros to the regional government to continue on that infrastructure. For its part, the government of Catalonia was willing to pay 7.5 million euros. Finally, given the impossibility of an agreement, Ryanair reduced from 30 to just 6 destimations in this airport for 2012 .
} 
to determine the relationship between public funds, the power of the carriers when negotiating the granting of public funds and finally the market power in the provision of air service. The lack of this information has only allowed us to estimate the average degree of market power at each airport, which may be a first approach for future work.

Acknowledgement 1 I am grateful to Pablo Coto-Millán for his valuable comments.

\section{References}

[1] Allroggen, F., Malina, R., Lenz, A.K. (2013) 'Which factors impact on the presence of incentive for route and traffic development? Econometric evidence from European airports' Transportation Research Part E, 60, pp. 49-61.

[2] Barbot, C. (2006) 'Low-cost airlines, secondary airports, and state aid: An economic assessment of the Ryanair-Charleroi Airport agreement' Journal of Air Transport Management 12, pp. 197-203.

[3] Bel, G. (2009) How to compete for a place in the world with a hand tied behind your back: The case of air transport services in Girona. Tourism Management 30(4), pp. 522-529.

[4] Bel, G. Fageda, X. (2009) Preventing competition because of 'solidarity': rhetoric and reality of airport investments in Spain Applied Economics, 41, pp. 2853-2865.

[5] Bottasso, A., Conti, M. and Piga, C. (2013) 'Low-cost carriers and airports' performance: empirical evidence from a panel of UK airports' Industrial and Corporate Change, 22(3), pp. 745-769.

[6] Cameron, A.C. and Trivedi, P.K. (2005) 'Microeconometrics: methods and applications' Cambridge University Press: Cambridge.

[7] CNC (2011) 'III Informe Anual Sobre Ayudas Públicas en España', Madrid: Comisión Nacional de la Competencia, pp.46-102.

[8] European Commission (2002) 'Study on competition between airports and the application of state aid rules', Final report.

[9] European Commission (2005) 'Community guidelines on financing of airports and start-up aid to airlines departing from regional airports', Official Journal of the European Union.

[10] European Commission (2014) 'Community guidelines on State aid to airports an airlines', Official Journal of the European Union. 


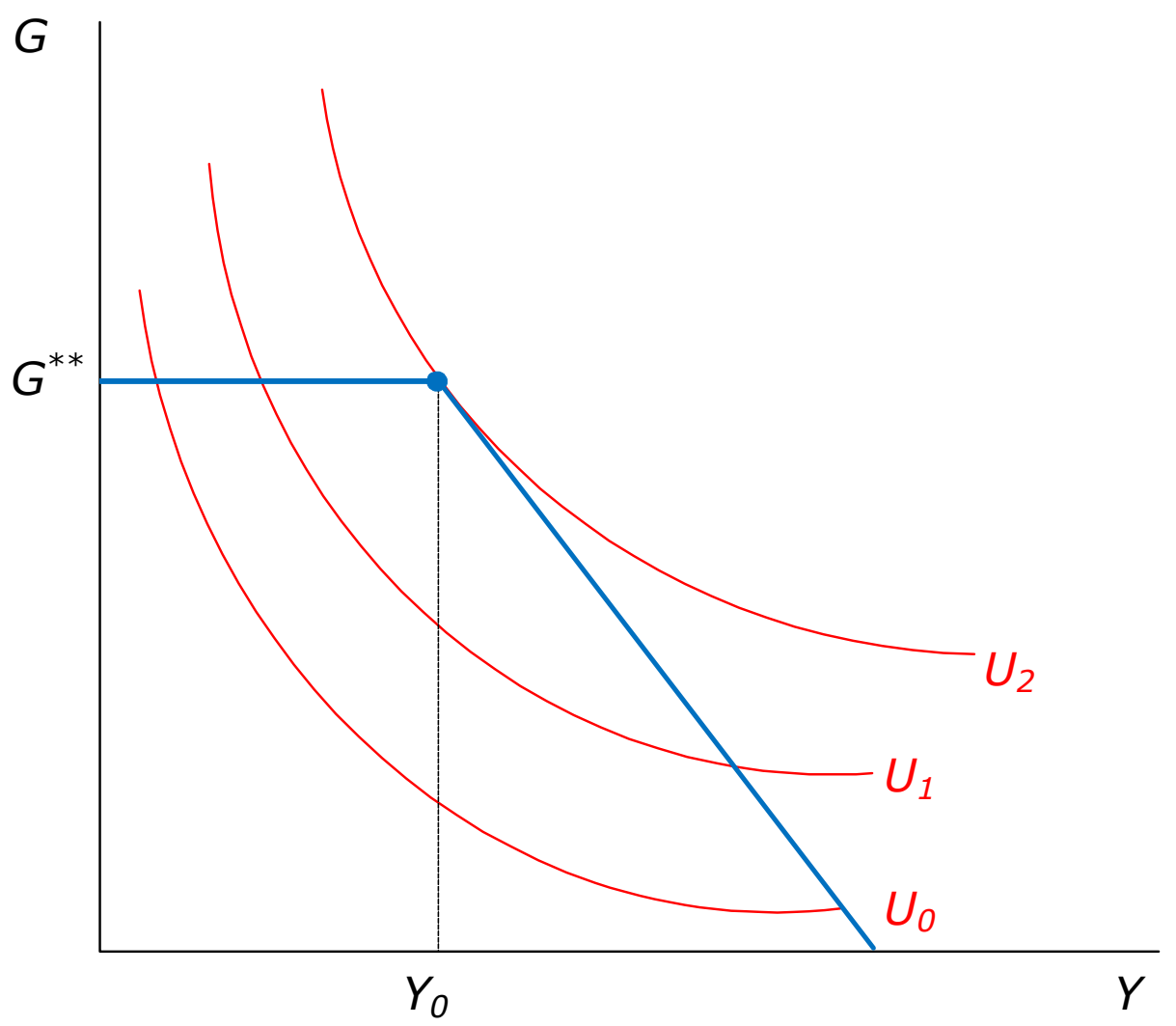

Figure 1: Equilibrium for public agency with no subsidies

[11] Gillen, D. (2011) 'The evolution of airport ownership and governance', Journal of Air Transport Management, 17(1), pp. 3-13.

[12] Malina, R., Albers, S and Kroll, N. (2012) 'Airport Incentive Programmes: A European Perspective', Transport Reviews, 32(4), pp. 435-453.

[13] Núñez-Sánchez, R. (2013) 'Marginal Costs, Price Elasticities of Demand and Second-best Pricing in a Multiproduct Industry: An Application for Spanish Port Infrastructure' Journal of Transport Economics and Policy, 47(2), pp.1-20.

[14] Wooldridge, J.M. (2002) 'Econometric analysis of cross section and panel data' MIT Press: Cambridge. 


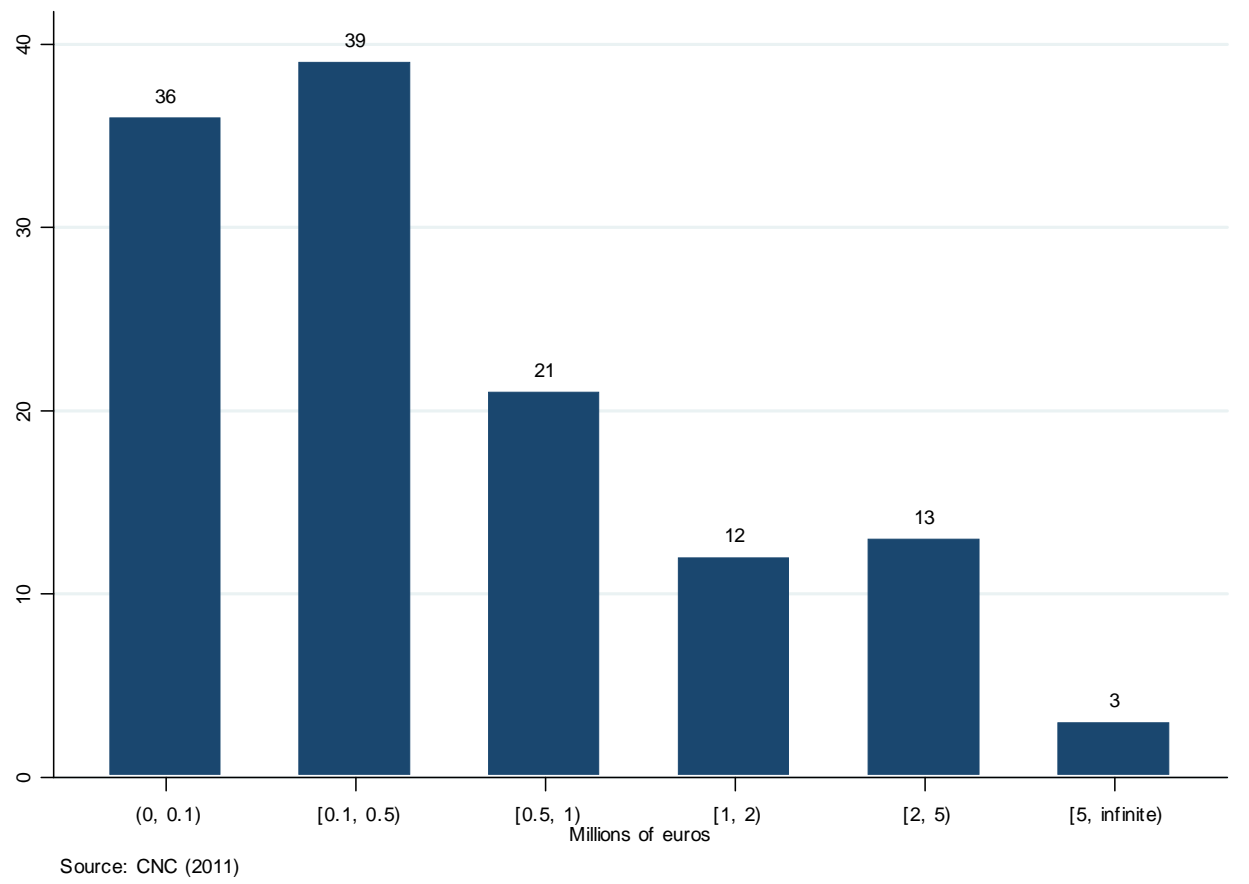

Figure 2: Distribution of annual contracts and agreements by economic value

Table 1: Summary statistics of variables

\begin{tabular}{llrrrr}
\hline \hline & Units of measure & Mean & Std. Dev. & \multicolumn{1}{c}{ Min } & \multicolumn{1}{c}{ Max } \\
\hline Average subsidy $(s)$ & Euros per aircraft & 152.7 & 391.8 & 0 & $3,061.9$ \\
Aircraft movements $(Y)$ & & 50,987 & 83,943 & 937 & 483,292 \\
Tourism-oriented budget $(B)$ & Million Euros & 162.7 & 236.2 & 7.4 & $1,061.1$ \\
Population $($ pop $)$ & Inhabitants & $1,273,182$ & $1,673,589$ & 10,558 & $6,458,684$ \\
Minimum distance of airports $($ dist $)$ & Kilometers & 86.8 & 35.9 & 24 & 183 \\
Airport category: First & & 0.27 & 0.44 & 0 & 1 \\
Airport category: Second & & 0.25 & 0.43 & 0 & 1 \\
Airport category: Third & & 0.48 & 0.5 & 0 & 1 \\
Herfindahl index $(H)$ & & 0.392 & 0.329 & 0 & 1 \\
\hline
\end{tabular}




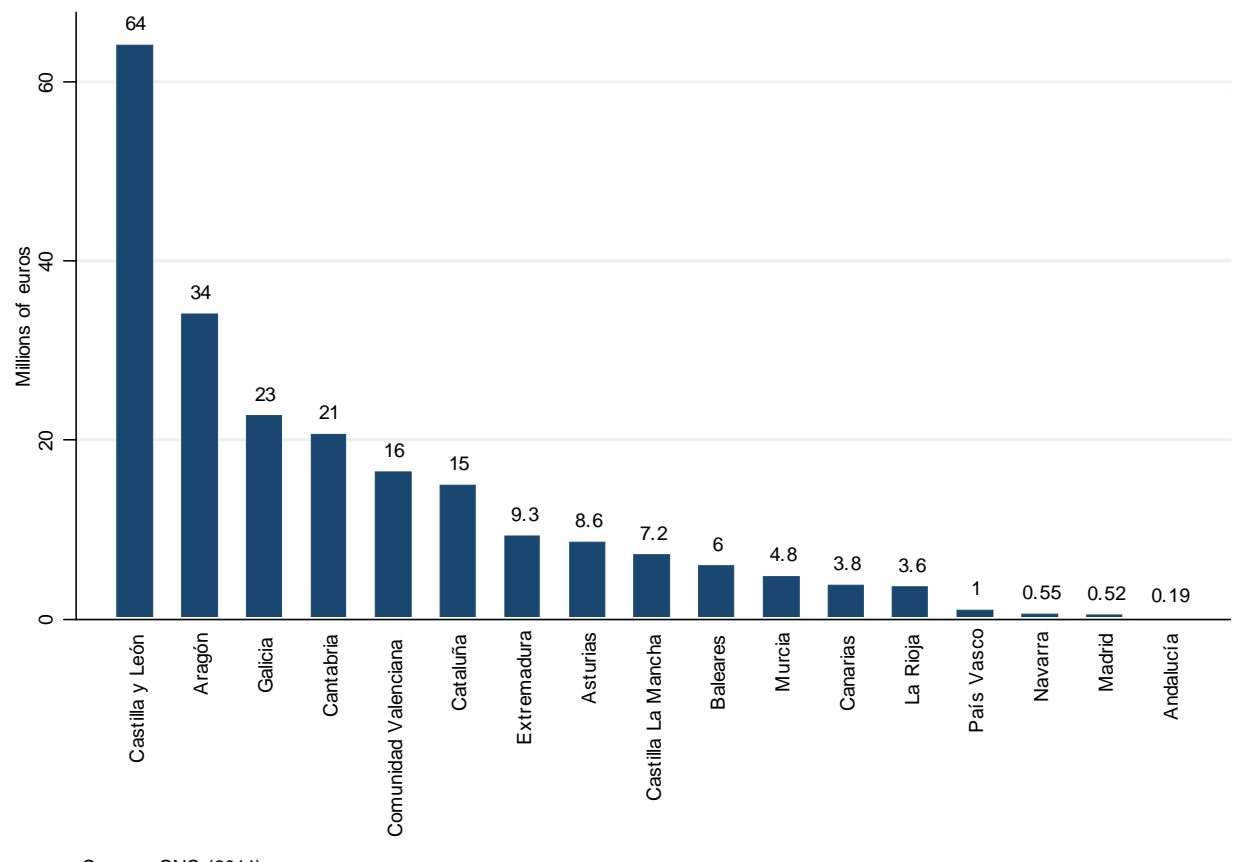

Figure 3: Distribution of regional public funds to contracts and agreements for the period 2007-2011 
Table 2: Estimates of the inverse demand function. Dependent variable: $\mathrm{s}$

\begin{tabular}{|c|c|c|}
\hline & $\begin{array}{c}(1) \\
\text { Tobit }\end{array}$ & $\begin{array}{c}(2) \\
\text { IV Tobit }\end{array}$ \\
\hline $\ln Y$ & $\begin{array}{c}-2.490^{* * *} \\
(-4.03)\end{array}$ & $\begin{array}{c}-4.314^{* * *} \\
(-4.31)\end{array}$ \\
\hline $\ln B$ & $\begin{array}{c}-2.904^{* * *} \\
(-5.93)\end{array}$ & $\begin{array}{c}-3.077^{* * *} \\
(-6.07)\end{array}$ \\
\hline $\operatorname{lnpop}$ & $\begin{array}{c}1.836^{* * *} \\
(3.37)\end{array}$ & $\begin{array}{c}3.198^{* * *} \\
(3.99)\end{array}$ \\
\hline lndist & $\begin{array}{c}3.354^{* *} \\
(3.09)\end{array}$ & $\begin{array}{c}3.136^{* *} \\
(2.80)\end{array}$ \\
\hline y07 & $\begin{array}{l}1.793^{*} \\
(2.13)\end{array}$ & $\begin{array}{c}2.416^{* *} \\
(2.67)\end{array}$ \\
\hline y08 & $\begin{array}{c}2.519^{* *} \\
(3.04)\end{array}$ & $\begin{array}{c}3.059^{* * *} \\
(3.48)\end{array}$ \\
\hline y09 & $\begin{array}{l}1.966^{*} \\
(2.42)\end{array}$ & $\begin{array}{c}2.285^{* *} \\
(2.71)\end{array}$ \\
\hline y10 & $\begin{array}{l}1.515 \\
(1.89)\end{array}$ & $\begin{array}{l}1.703^{*} \\
(2.07)\end{array}$ \\
\hline Constant & $\begin{array}{l}-3.642 \\
(-0.71)\end{array}$ & $\begin{array}{l}-1.730 \\
(-0.32)\end{array}$ \\
\hline Regional dummies & Included & Included \\
\hline Wald test of exogeneity & & $3.31^{*}$ \\
\hline $\operatorname{lns}$ & & $\begin{array}{c}1.191^{* * *} \\
(18.61)\end{array}$ \\
\hline $\operatorname{lnv}$ & & $\begin{array}{c}-1.196^{* * *} \\
(-24.34) \\
\end{array}$ \\
\hline$N$ & 207 & 207 \\
\hline
\end{tabular}


Table 3: Elasticities of average public funds for different values of aircraft operations

\begin{tabular}{ccc}
\hline \hline & $(1)$ & $(2)$ \\
& Tobit & IV Tobit \\
\hline $5 \%$ percentile & $-2.391^{* * *}$ & $-4.270^{* * *}$ \\
$Y=2,737$ & $(-3.73)$ & $(-4.19)$ \\
& & \\
$50 \%$ percentile & $-1.99^{* * *}$ & $-3.346^{* * *}$ \\
$Y=18,852$ & $(-4.13)$ & $(-4.83)$ \\
& & \\
$95 \%$ percentile & $-1.125^{* * *}$ & $-0.965^{* * *}$ \\
$Y=186,759$ & $(-19.22)$ & $(-6.7)$ \\
& & \\
\hline \hline$t$ statistics in parentheses & \\
${ }^{*} p<0.05,{ }^{* *} p<0.01,{ }^{* * *} p<0.001$
\end{tabular}


Table 4: Estimates of the markups

\begin{tabular}{|c|c|c|c|}
\hline Albacete & $\begin{array}{c}2.793^{* * *} \\
(-4.31)\end{array}$ & Menorca & $\begin{array}{c}0.567^{* * *} \\
(4.24)\end{array}$ \\
\hline Alicante & $\begin{array}{c}0.475^{* * *} \\
(-4.11)\end{array}$ & Málaga & $\begin{array}{l}0.007 \\
(1.07)\end{array}$ \\
\hline Almería & $\begin{array}{c}0.506^{* *} \\
(2.65)\end{array}$ & Melilla & $\begin{array}{c}3.871^{* * *} \\
(4.35)\end{array}$ \\
\hline Asturias & $\begin{array}{c}0.959^{* * *} \\
(4.31)\end{array}$ & Palma de Mallorca & $\begin{array}{c}0.613^{* * *} \\
(4.29)\end{array}$ \\
\hline Badajoz & $\begin{array}{c}3.817^{* * *} \\
(4.31)\end{array}$ & Pamplona & $\begin{array}{l}0.855 \\
(1.69)\end{array}$ \\
\hline Burgos & $\begin{array}{c}2.976^{* * *} \\
(4.31)\end{array}$ & Reus & $\begin{array}{c}3.929^{* * *} \\
(3.97)\end{array}$ \\
\hline A Coruña & $\begin{array}{c}1.332^{* * *} \\
(4.3)\end{array}$ & Salamanca & $\begin{array}{c}2.244^{* * *} \\
(4.7)\end{array}$ \\
\hline Fuerteventura & $\begin{array}{c}0.264^{* * *} \\
(5.14)\end{array}$ & San Javier & $\begin{array}{c}2.311^{* * *} \\
(4.31)\end{array}$ \\
\hline Girona & $\begin{array}{c}3.951^{* * *} \\
(4.19)\end{array}$ & San Sebastián & $\begin{array}{l}1.029^{*} \\
(1.96)\end{array}$ \\
\hline El Hierro & $\begin{array}{c}2.580^{* * *} \\
(4.27)\end{array}$ & Tenerife Sur & $\begin{array}{c}0.345^{* * *} \\
(3.85)\end{array}$ \\
\hline Ibiza & $\begin{array}{c}0.387^{* * *} \\
(4.47)\end{array}$ & Tenerife Norte & $\begin{array}{c}0.685^{* * *} \\
(3.84)\end{array}$ \\
\hline Lanzarote & $\begin{array}{c}0.212^{* * *} \\
(5.18)\end{array}$ & Santander & $\begin{array}{c}2.399^{* * *} \\
(4.31)\end{array}$ \\
\hline La Palma & $\begin{array}{c}0.907^{* * *} \\
(4.53)\end{array}$ & Santiago & $\begin{array}{c}0.844^{* * *} \\
(4.35)\end{array}$ \\
\hline La Rioja & $\begin{array}{c}3.696^{* * *} \\
(4.31)\end{array}$ & Valencia & $\begin{array}{c}0.783^{* * *} \\
(4.3)\end{array}$ \\
\hline La Gomera & $\begin{array}{c}4.234^{* * *} \\
(4.09)\end{array}$ & Valladolid & $\begin{array}{c}1.985^{* * *} \\
(4.38)\end{array}$ \\
\hline León & $\begin{array}{c}2.760^{* * *} \\
(4.31)\end{array}$ & Vigo & $\begin{array}{c}1.032^{* * *} \\
(4.31)\end{array}$ \\
\hline Gran Canaria & $\begin{array}{c}0.383^{* * *} \\
(4.49)\end{array}$ & Zaragoza & $\begin{array}{c}2.045^{* * *} \\
(4.2)\end{array}$ \\
\hline Madrid-Barajas & $\begin{array}{c}0.509^{*} \\
(2.42)\end{array}$ & & \\
\hline
\end{tabular}




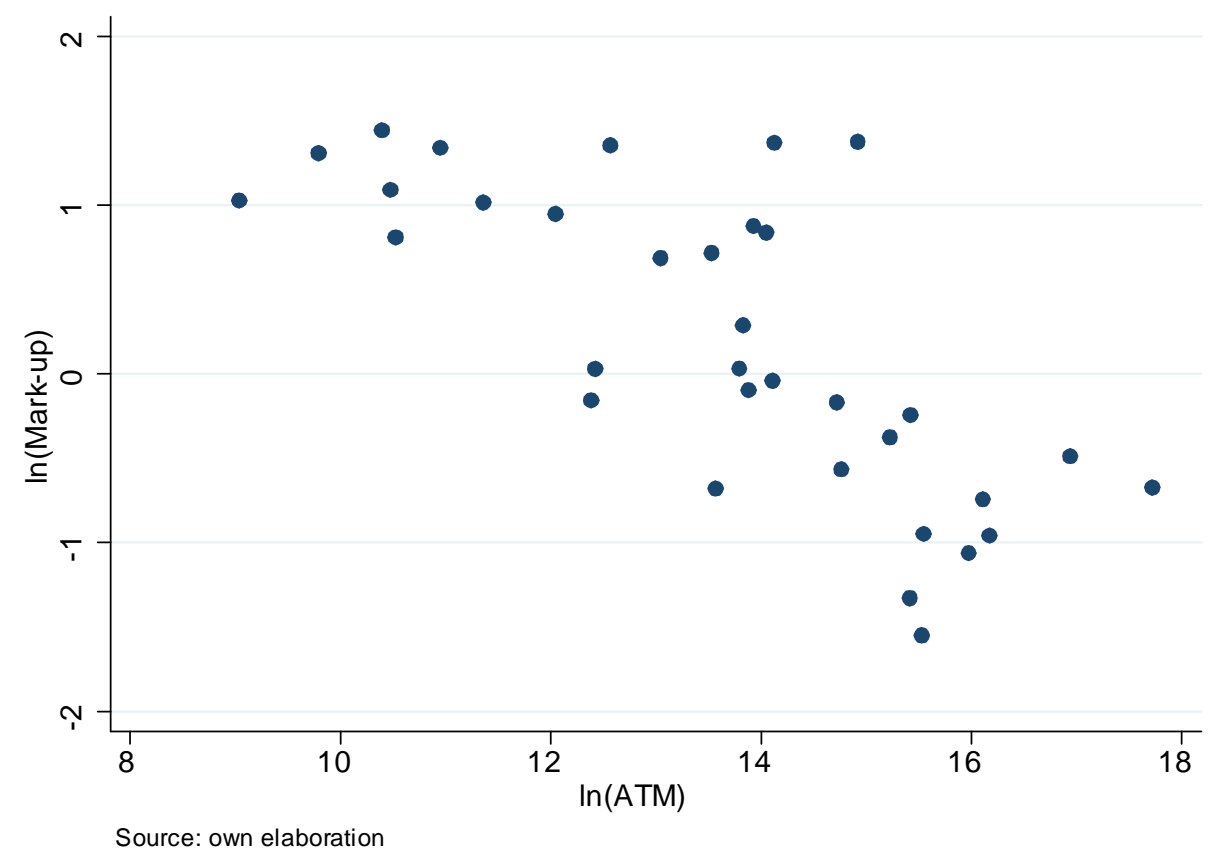

Figure 4: Relationship between ATM and average mark-up for airlines 